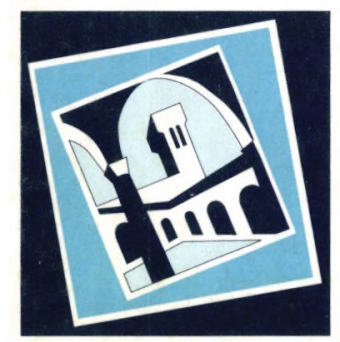

EUROPEAN UNIVERSITY INSTITUTE The Robert Schuman Centre

\title{
The Varieties of Eurosclerosis: The Rise and Decline of Nations since 1982
}

\section{Mancur Olson JR.}


EUROPEAN UNIVERSITY INSTITUTE

|| || |||||||||||||||||||||||||||||||||||||||||||||||||||||

30001002669424 


\section{Jean Monnet Chair Papers}

\section{Olson Jr.: The Varieties of Eurosclerosis}

The Rise and Decline of Nations since 1982

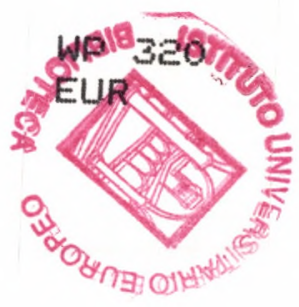




\section{Jean Monnet Chair Papers}

\section{The Jean Monnet Chair}

The Jean Monnet Chair was created in 1988 by decision of the Academic Council of the European University Institute, with the financial support of the European Community. The aim of this initiative was to promote studies and discussion on the problems, internal and external, of European Union following the Single European Act, by associating renowned academics and personalities from the political and economic world to the teaching and research activities of the Institute in Florence. 


\section{Jean Monnet Chair Papers}

\section{The Varieties of Eurosclerosis}

The Rise and Decline of Nations since 1982

MANCUR Olson JR.

\section{5}

The Robert Schuman Centre at the European University Institute 
All rights reserved.

No part of this paper may be reproduced in any form without permission of the author.

(c) Mancur Olson Jr.

Printed in Italy in December 1995

European University Institute

Badia Fiesolana

I-50016 San Domenico (FI)

Italy 


\section{Table of Contents}

Introduction

p. 7

I. A Recapitulation of the Theory

p. 8

The Incentives Facing Organizations for Collective Action

p. 10

Testable Implications of the Theory

p. 11

Generalizing the Theory for Communism and the Transition

Better Economic Understanding as the Antidote

p. 13

p. 14

II. Economic Growth since Rise and Decline

p. 15

III. Distinctive Institutions and Common Processes

p. 20

Anglo-American

p. 21

Mercantilistic

p. 21

Red Devolution

p. 21

Healing-of-Divisions Sclerosis: southern Europe

p. 22

Devolution of Encompassing Interest Groups:

northern Europe

Different Beginnings, Similar Endings

p. 25

p. 33

IV. Distinctive Institutions and Inescapable Logic

p. 34

Biographical Note

p. 37 


\section{Introduction 1}

Valuable as they are, conventional economic models have not succeeded in explaining the great differences in economic performance in different countries or historical periods. The "old" growth theory is called into question by the absence of the convergence in per-capita income levels across the globe that it leads one to expect. The "new" growth theory readily accommodates continuing differences in per-capita incomes across countries but does not yet provide much insight into why the particular countries that became rich were the ones that grew. Nor does it explain why a few poor countries have led the world in economic growth at the same time that the poor countries as a whole have not been catching up.

In a book, The Rise and Decline of Nations ${ }^{2}$, some article-length publications that foreshadowed it, and some subsequent papers and publications that focused on Eastern Europe and on the Third World 3 , I presented a theory that combines the insights of familiar neoclassical economic models with a model of collective choice. The model of collective choice enables the theory to comprehend certain aspects of political and organizational life. The theory succeeds in explaining the most dramatic and puzzling variations in economic performance across countries.

1 I am grateful to the US Agency for International Development for support of my research through the Center for Institutional Reform and the Informal Sector (IRIS) at the University of Maryland. This support has facilitated my development of the general theory used here and particularly its application to the formerly communist countries and the Third World. I have also benefitted from a travel grant from the Thyssen Stiftung and from criticisms by Christopher Bartlett, Carol Kaplan, Nicholas Crafts, Lars Jonung, and R.C.O. Matthews.

2 New Haven and London: Yale University Press, 1982.

3 "The Devolution of Centrally Planned Economies", (with Peter Murrell) initially presented in tentative form to various audiences in the mid- and late-1980's and published in the Journal of Comparative Economics 15, 239-265 (1991)., "The Logic of Collective Action in Soviet-type Societies", Journal of Soviet Nationalities, Vol. I, No. 2, Summer 1990, pp. 8-33., "The Exploitation and Subsidization of Agriculture in the Developing and Developed Countries", in Agriculture in a Turbulent World Economy: Proceedings of the Nineteenth International Conference of Agricultural Economists, held at Malaga, Spain August 26 -September 4, 1985, Edited by Allen Maunder and Ulf Renborg (Brookfield, Vermont: Gower Publishing Company, 1986, pp. 49-59); "The Hidden Path to Economic Development", in Christopher Clague and Gordon Rausser, The Emergence of Market Economies in Eastern Europe (Basil Blackwell, Inc. 1992), pp. $55-75$. 
The present essay will differ from the aforementioned book and articles in two ways.

First, this essay will attempt to show how the same fundamental forces that influence economic performance everywhere show up in very different forms in countries with different initial conditions. Even when one considers only the related and similar societies of Western Europe, the institutional and historical differences across countries not only have a significant independent effect on outcomes, but they also make the same fundamental forces take on a totally different appearance. Just as a change in temperature can turn water into ice or steam, so international differences in institutions can make a single, general force operating in different countries appear to be a variety of unrelated phenomena. This essay will show that some apparently unrelated developments in Europe are, in fact, manifestations of the same process.

Second, this essay will focus only on economic growth since Rise and $D e$ cline was written. Any theory should be able to explain data beyond the data from which it was derived. Obviously, I could not have known, when writing the book, about developments that occurred after the book was published. Thus the theory could not possibly have been adjusted to take account of the developments that are the focus of the present essay.

Since my discussion will not be comprehensible unless the reader has some knowledge of the theory developed in prior works, Section I outlines some of the ideas from prior publications that will be used and tested in this essay Readers who know both Rise and Decline and my subsequent papers on the communist and post-communist societies can skiD this section.

\section{A Recapitulation of the Theory}

The theory begins with collective action - concerted efforts to lobby the government or to combine in the marketplace to influence prices and wages. Such action occurs through professional associations, labor unions, farm organizations, trade associations, and oligopolistic collusions of firms in concentrated industries.

The benefits of the governmental favors and the monopolistic or monopsonistic prices or wages obtained by organized action go to every firm or individ- 
ual in some group or category. For example, a tariff or tax loophole favors every firm in some industry or group, and cartelization raises the price or wage for every seller of a good. It follows that any sacrifice an individual makes to support a lobby or cartel for his group will benefit others as much as himself. A group with a common interest will be able to overcome this collective good problem only if it has the advantage of small numbers or is blessed with access to "selective incentives".

The advantage of small numbers is clearest in a concentrated industry containing only a few large firms. If there are two firms of the same size in an industry, each firm will obtain half of the benefit of any action in the interest of the group. Even though each firm must bear the whole cost of whatever it does for this group of two firms, it's large share of the benefit will often be sufficient to give it an incentive for some unilateral action in the interest of the group. If there are, by contrast, a million individuals in a group with a common interest, a representative individual in the group will receive only a millionth of the benefits of any action he or she takes in the interest of the group. Each individual will still have to bear the whole cost of whatever he or she does in the interest of the group. As these examples make obvious, the incentive to act in the interest of the group must be less in large than in small groups, and in really large groups the incentive for an individual to engage in spontaneous collective action is vanishingly small.

When a large number of people share a common interest, they will be able to act collectively to serve this interest only if they have selective incentives. A selective incentive is a reward or punishment that, unlike the benefits of the collective good itself, selectively applies to individuals according to whether they do or do not contribute to the provision of the collective good, and therefore gives the individuals an incentive to act in the group interest. Probably the best known selective incentives are the closed shop, the union shop, and the coercive picket line - those who do not share the costs of the collective action are threatened with loss of a job or are subject to social or physical intimidation. Though the selective incentives used by other kinds of large organizations for collective action are usually less conspicuous, they are no less important ${ }^{4}$.

4 The logic of the foregoing argument is demonstrated in The Logic of Collective Action (Cambridge, Mass., Harvard Univ. Press, 1965). The findings of much of the best subsequent literature on the topic are cited in Russell Hardin, Collective Action (Baltimore: Johns Hopkins U. Press, 1982) and in Todd Sandler Collective Action (Ann Arbor: U. of Michigan Press 1992). 
Since collective action is difficult and problematical, it usually takes quite some time before a group can engage in collective action, even when it has small numbers or the opportunity to devise selective incentives. The bargaining that is required for those in small groups to organize or collude with full effectiveness often takes a while. Organizing large groups is incomparably more difficult and time consuming. It is only in the fullness of time that many groups will have had the able leadership and the favorable circumstances needed to organize for collective action.

\section{The Incentives Facing Organizations for Collective Action}

What difference does it make for the prosperity of a society how many groups, and what kinds of groups, are organized for collective action? The answer is evident when we look at the incentives that organizations for collective action face.

The constituents of any organization that represents only a narrow segment of the society will virtually always be better off if the organization shifts the distribution of income in the society in their favor. An organization for collective action can shift the distribution of income in the society through lobbying for special-interest legislation - for subsidies, tariffs, tax loopholes, or regulations that limit entry and competition. It can shift the distribution of income in its favor by selling less and charging more for it - that is, by collusion or cartelization.

In general, special-interest legislation and monopolistic combination makes an economy less productive than it would have been, and the constituents of an organization for collective action will share the losses. But an organization for collective action that represents only a narrow segment of the society will bear only a minuscule share of these losses. A special-interest organization whose constituents earn $1 \%$ of the national income will, on average, bear only $1 \%$ of the loss in national output that occurs because of the inefficiency its activities bring about. But the special interest obtains the whole of the amount redistributed to it. Thus it pays our hypothetical special-interest group to seek to redistribute income to its own members even if this redistribution reduces the national income by up to 100 times the amount redistributed.

Therefore, organizations that represent only a minute percentage of an economy's income-earning capacity are really "distributional coalitions" - 
coalitions whose purpose is to redistribute more of society's income to themselves.

If an organization for collective action encompasses a large part of the income-earning capacity of a country, its incentives are very different. This is immediately evident if one considers an organization that represents, say, half of the income-earning capacity of a society; its clients will on average obtain one-half of any increase in the national income that it brings about and bear half of the social loss that results from redistributions to itself There have been such encompassing interest organizations in Austria, Norway, and Sweden, and to a lesser extent in Germany and Japan.

The concept of an encompassing interest applies to many different types of situations, offices, and individuals. A dictator has an encompassing interest in any domain which he securely controls: his tax receipts, which will increase with the productivity of his country, give him this encompassing interest ${ }^{5}$. Though a large organization cannot usually optimize as effectively as a single individual, a large and well-disciplined political party, such as the Conservative Party in Great Britain or the Social Democratic Party in Sweden, also has an encompassing interest. So does a president in strong-presidency countries like France and the United States; a president normally needs majority support to be re-elected, and a majority is an encompassing constituency.

Some of the conclusions of the present argument hinge on this concept of the encompassing interest, and much of the later part of this essay is devoted to an analysis of the dynamics of encompassing special-interest organizations.

\section{Testable Implications of the Theory}

The ideas that have just been evoked can explain the most striking anomalies in modern economic growth. We have seen that organizations for

5 The concept of encompassing interests has only been extended to dictatorships and analyzed in a formal way since Rise and Decline was published, e.g., in Martin C. McGuire and Mancur Olson, "Dictatorship, Democracy, and the Provision of Public Goods", Department of Economics and IRIS, Univ. of Maryland, Dec., 1990, and in "The Economics of Autocracy and Majority Rule: The Invisible Hand and the Use of Force", (IRIS, Univ. of Maryland and Univ. of California, Irvine, 1994) and forthcoming, Journal of Economic Literature, and in my "Autocracy, Democracy, and Prosperity", in Strategy and Choice, edited by Richard J. Zeckhauser (Cambridge, MA: The MIT Press, 1991), pp. 131-57 and "Dictatorship, Democracy, and Development", American Political Science Review, Vol. 87, No.3, (Sept., 1993), pp. 567-76. 
collective action with narrow constituencies have uniquely perverse incentives, and that it takes a long time before a society accumulates many organizations for collective action. Revolutionary upheavals, totalitarian repressions, and foreign occupations destroy organizations for collective action. In any brief interval of stability, few if any groups can overcome the difficulties of collective action. By contrast, in a long-stable society, many groups will have overcome these obstacles. Once these organizations have worked out the selective incentives or agreements needed for collective action, they rarely disappear unless they are violently repressed. Thus only long-stable societies are thick with organizations for collective action.

Distributional coalitions are, if my argument is correct, uniquely harmful to economic efficiency and dynamism. It follows that societies that set up a good legal order, after a catastrophe has destroyed organizations for collective action, will grow extraordinarily rapidly for a time. Similarly, long-stable societies ought to grow much less rapidly than societies that are in other respects comparable. Thus we can test the theory by asking whether it fits the facts about economic performance in different countries.

The society that has had the longest period of stability and immunity from invasion and institutional destruction is Great Britain. As the theory predicts, Great Britain has also had the "British disease" - the poorest economic performance, for most of the postwar period, of the major developed democracies. The economic miracles of Germany and Japan after World War II are also consistent with the argument. In Italy, the institutional destruction in World War II, while considerable, was less complete than in Germany and Japan. Though there definitely was an economic miracle in Italy, it was correspondingly somewhat shorter and smaller than those in Germany and Japan, and this again is in accord with the theory. With appropriate elaboration 6 , the aforementioned theory also explains the general pattern of regional growth in the United States since World War II.

Consider also the most remarkable examples of economic growth in previous centuries: the growth of Germany after the Zollverein or customs union was established in 1834 and after German unification was completed by 1871 , the growth of Japan after the Meiji Restoration of 1867-68, the growth of the United States in the 19th century, the growth of Holland during its Golden Age in the 17th century, the growth of Britain during the Industrial Revolution

6 See "The South Will Fall Again: The South as Leader and Laggard in Economic Growth”, Southern Economic Journal, vol. 49 (April 1983), pp. 917-932. 
from about 1760 to about 1840, and the commercial revolutions in England and France in the 16th century.

All of these cases illustrate what I called "jurisdictional integration": in each case, a wider market was created within which there was at least internal free trade, and at the same time a new jurisdiction or government was established that could be influenced only by lobbies that were of a larger scale than most of those that had influenced the parochial jurisdictions that existed before.

After the creation of the much larger jurisdiction and the wider market, there was in every case rapid economic growth. Jurisdictional integration undercut the guilds and other special-interest groups of the day. A detailed examination reveals that not only the speed of development after the jurisdictional integration, but also its organizational features and regional patterns are consistent with the theory, as is much of the subsequent literature ${ }^{7}$.

\section{Generalizing the Theory for Communism and the Transition}

Though Rise and Decline said nothing about the Soviet-type countries, the theory in it was soon generalized to cover these societies and other dictatorships, and then later to deal with the transition from communism. Under Soviet-type dictatorships, there was, of course, no freedom of organization, so there were no formal lobbying organizations, independent labor unions, or other explicitly cartelistic organizations. Thus it might seem that under communism there could not have been any collective action that impaired economic performance.

7 See, for example, Kwang Choi, Theories of Economic Growth (Ames, IA., Iowa State University Press, 1983); Richard Vedder and Lowell Galloway, "Rentseeking, Distributional Coalitions, Taxes, Relative Prices, and Economic Growth", Public Choice, vol. 51 no. 1 (1986), pp. 93-100, Steve Chan, "Growth with Equity: A Test of Olson's Theory for the Asian Pacific-Rim Countries", Journal of Peace Research, vol. 24, no. 2 (1987), pp. 135-49, Erich Weede, "Catch-Up, Distributional Coalitions and Government as Determinants of Growth and Decline in Industrial Democracies", British Journal of Sociology, vol. 37 (1986), pp. 194-220; Jan-Erik Lane and Svante Ersson, Comparative Political Economy (New York: Pinter Publishers, 1990); Todd Sandler, Collective Action: Theory and Applications (Ann Arbor: University of Michigan Press, 1992); Jonathan Rauch, Demosclerosis (New York: Times Books, 1994); and many of the contributions in the following collections of assessments and test of the Rise and Decline of Nations: Dennis C. Mueller, ed., The Political Economy of Growth (New Haven, Yale Univ. Press, 1983); International Studies Quarterly, vol. 27 (1983); Scandinavian Political Studies, Vol. 9 (March 1986). 
I claim that, in fact, the dictator in a Soviet-type system is utterly dependent tor information on bureaucratic competition among subordinates in individual industries and enterprises, and that the subordinates in each industry and enterprise can, if they covertly collude, distort the information flow going to the center in ways that enable them to obtain surplus resources to serve their own interests. Thus covert collective action ultimately creates innumerable nomenklatura collusions and, in the fullness of time, this devolution reaches the point where large enterprises and industry associations are as much insider lobbies and monopolies with vested interests as they are instruments of production to serve the communist regime. Each collusion, enterprise, and industry has so small a stake in the productivity of the society as a whole that each tends to ignore its impact on the society. In this the individual collusions and enterprises are very different from the General Secretary of a communist country, who has an encompassing interest in the productivity of his domain and therefore a motive to make it as productive as possible. Thus, in the absence of organizationally destructive events like China's cultural revolution, the theory predicts that the economic performance of stable Soviet-type societies deteriorates over time. Since the enterprises and industries are not destroyed by the transition to democracy, but are, on the contrary, given an new freedom to lobby for their sectional interests, this problem is magnified during the transition.

Since the focus here is on Western Europe, I will not discuss the other testable predictions of the theory for Soviet-type and transitional societies but will return to developed democracies.

\section{Better Economic Understanding as the Antidote}

The theory argues that it is mainly narrow as opposed to encompassing organizations that repress economic growth. Each narrow special-interest organization represents only a tiny minority of the population. Therefore, in any democracy it can easily be outvoted. A special interest can get its way only because most of the society does not notice or understand what is happening. Thus Rise and Decline emphasized the quality of economic thought and the extent of economic literacy. It argued that, if societies came to understand and believe the argument in Rise and Decline, the predictions in the book would be refuted.

Since both the level of economic understanding and the density of organizations for collective action are important determinants of economic perfor- 
mance, each needs to be kept in mind in any attempt to trace the influence of the other. A country may grow faster or slower than would be expected from its density of organization for collective action because its understanding of the problem - and of what is required for an efficient and dynamic economy - is better or worse than in comparable countries. It is even conceivable that societies with more serious cases - or less opaque forms - of institutional sclerosis apprehend the problem more quickly than other societies ${ }^{8}$. This means that we must keep both the character of collective action and the prevailing economic ideas in a country in mind when analyzing economic growth since 1982.

\section{Economic Growth since Rise and Decline}

Some of the best evidence in support of the theory outlined above comes from communist and formerly communist countries. In the early postwar period the communist countries grew relatively rapidly. But as time went on they suffered a gradual and continuing deterioration in their growth rates, in spite of their continued opportunities for fast catch-up growth. It was only after a long period of relative decline that communism collapsed.

The sharply contrasting consequences of the defeat of fascist and communist regimes fits the theory especially nicely. Whereas the defeat of fascism destroyed most organizations for collective action, the defeat of communism gave the lobbies of large enterprises and industry associations the opportunity to use their political muscle openly. The defeat of fascism was followed by economic miracles in all of the formerly Axis countries, but the defeat of communism has so far often been followed by even poorer performance than under communism. The only communist or once-communist country that has enjoyed an economic miracle is the one that suffered the cultural revolution (and after this revolution China was ruled by a pragmatic dictator with an encompassing interest in a productive domain). This is indeed the exception that proves the rule. But the focus here is on the West, so I turn to the less dramatic changes that have occurred in the developed democracies.

8 This possibility, and the role of economic ideas generally, is discussed in "How Ideas Affect Societies: Is Britain the Wave of the Future?" in Ideas Interests and Consequences, (London: Institute of Economic Affairs, 1989), also republished in The LSE Quarterly, Winter, 1989. 
A most interesting pattern of gradual change through time has been evident in the countries whose fascist regimes were defeated in World War II. The logic of the argument in Rise and Decline implied that the same accumulation of organizations for collective action that had troubled the long-stable English-speaking countries would also occur, if these countries remained stable, in Germany and Japan as time went on. This prediction was made explicitly:

"The theory here predicts that with continued stability the Germans and Japanese will accumulate mare distributional coalitions, which will have an adverse influence on their growth rates" 9 . The same argument was made separately with respect to Italy. When Rise and Decline was being written, Germany and Italy were already experiencing some reduction in relative growth rates, but at that time this relative decline had not attracted much attention outside of those countries. The almost universal forecast at that time was that the Japanese economic miracle would continue.

By now it is beyond dispute that the Japanese as well as the German and Italian economic miracles are over. In the 1950's and 60's, real per-capita incomes in Germany and Japan grew more than three times as fast as those of the UK, the US, Ireland, Australia, and New Zealand. Since 1980 the average rate of growth of per-capita income in the English-speaking OECD countries has been as great, and often even greater, than that of Germany and Japan.

Rise and Decline also argued that there was some institutional destruction in the continental countries that were under Axis occupation during World War II, and that many distributional coalitions in France and in some of the other previously protectionist countries were rendered ineffective by jurisdictional integration as the initial six countries created the Common Market. The jurisdictional integration due to the formation of the Common Market gave the six original members some growth advantage, for a period of time, over the long-stable English-speaking OECD countries. Again, the theory in Rise and Decline predicted that with continued stability in the Common Market countries, the growth-enhancing effects of the jurisdictional effects would gradually wear off as new patterns of collective action accumulated.

Again, this is what seems to have happened. In the 1960's per-capita incomes in France, Italy, Belgium, and the Netherlands all grew at more than $4 \%$ per year, whereas the English-speaking OECD countries grew at far 
slower rates. Since 1980, by contrast, these countries have grown no faster and sometimes slower - than the English-speaking OECD countries.

Countries with the most encompassing interest organizations also have slowed down over time. In the 1950's and 60's Sweden, in spite of its already relatively high level of per-capita income, grew faster than the English-speaking countries. The growth rates of Austria, Norway, and (as we already know) West Germany were also well ahead of those of the English-speaking countries. In the 1980's (and especially the 1990's) Swedish economic growth has fallen far behind that of the English-speaking countries, and that is also true of most of the other European countries that had enjoyed relatively encompassing interest group structures.

Whether we look at the growth rates of the communist countries, or at Germany, Japan, and Italy, or at the continental countries that were occupied by the Nazis in World War II, or at countries like Sweden that have had encompassing interest-group structures, we see that the changes are not only in the direction predicted by the theory, but also have the gradual character that would be expected from a sclerotic institutional accumulation.

Nonetheless, even though the aggregate evidence on national growth rates that has emerged since 1982 is certainly supportive of the theory, this aggregate evidence by itself is by no means compelling. As we know, economic growth is influenced by many different factors. It is obviously possible that other factors that influence growth rates could have explained the observed pattern so that the conformity with the theory in Rise and Decline is spurious.

There is also another and more intriguing possibility. We recall that, if the theory in Rise and Decline were generally understood and accepted, the predictions of theory would necessarily be refuted, and, more generally, that the intellectual climate influences choices about economic policy and is therefore extremely important. It is possible that the countries that suffered the most (or suffered in the least opaque ways) from special-interest cartelization and lobbying would be more susceptible to analyses of the problem, and come to have a bit more of an apprehension of it, than societies that had-suffered less (or in ways that were harder to understand). At least if the issue is explicitly discussed, the degree of understanding of the damage done by distributional coalitions could be, at least to some extent, endogenous.

Rise and Decline pointed out that two countries that had suffered extraordinarily severe institutional sclerosis - not only because of their long-standing 
stability but also because of their small size and then-exceptional propensities to industrial protectionism (the opposite of jurisdictional integration) - were Australia and (especially) New Zealand. Interestingly, labor governments in both New Zealand and Australia have undertaken widespread market-opening and deregulatory reforms that seem greatly to have weakened special-interest organizations on the business side. As might be expected, these labor parties, dependent in part on support from labor unions, have not taken the same strong stand against cartelization in the labor force. Similarly, the deregulation of the thoroughly cartelized and lobby-intensive industries such as airlines, trucking, telephones, and railroads in the United States, mainly during the President Carter's Democratic administration, owed something to the conspicuous economic irrationalities that special-interest pressures had brought to these industries.

The beginnings, during the Callaghan Labour government in the United Kingdom, of a reliance on limiting the money supply rather than only on in comes policies to restrict inflation, could be interpreted in a similar way. De spair, even in the British Labour party, about Britain's anything-but- encompassing trade unions also led a substantial part of the Labour leadership te leave that party to create a new political party. This step - which was all the more extraordinary because the British electoral system makes the defeat of any third party almost inevitable - could also be analyzed as a response to the severity of institutional sclerosis in Britain. As we know, the phenomenon there has been prolonged and serious enough to come to be called the Britis disease, and this surely generated demand for cures, even if they should be painful.

Thus, in the same way, Thatcherism can also be taken to be endogenous even as the mirror image of the labor or left-inspired reforms in New Zealand and Australia. Just as the reforms inaugurated by the labor governments of the South Pacific focused disproportionately on reversing the losses arising from cartelization and lobbying by business, naturally the Thatcher government focused on limiting the harm done by the special-interest groups that were linked with the left: the labor unions, which are also the most visible part of the special-interest iceberg.

Intriguing as the foregoing possibility of endogenous response to institutional sclerosis is, I must emphasize that I have not been able to undertake the multicountry study of political, economic, and intellectual history that would be needed to know how much truth it contains. The more important point for now is that no monocausal explanation of complex historical developments can 
be correct, including any such explanation drawn from the theory that I have offered. A series of factors that are not accounted for by the theory in Rise and Decline could have made the observed pattern of growth rates since 1982 spuriously consistent with the theory. Some of these other factors could even have operated in such a way as to generate the gradual character of the observed changes.

There is some additional evidence in the economic literature on continental and Nordic Europe in the 1980's and 1990's. In a series of papers and lectures starting in 1976, and in Rise and Decline, I used the phrases "institutional sclerosis" and "institutional arthritis" to label the process that my theory predicted 10 . Thus there is perhaps a little support for my argument in the emergence, in continental Europe in the 1980's, of the term "Eurosclerosis", which I have borrowed for the title of the present paper. The German economist Herbert Giersch appears to have coined the term, which also has currency in the popular press, and Assar Lindbeck gave sustained attention to the increasing sclerosis in continental and Nordic Europe in 198211. In Sweden, Stahl and Wickman have used the more targeted label of "Suedosclerosis" in the title of a recent book, and this coinage also appears to be spreading 12. Though the economists who use the sclerotic analogy have somewhat different emphases, the varied accounts nonetheless resonate with each other and with the argument here. Many expert observers with detailed knowledge of the economies of Germany, Sweden, and continental Europe find an increasing economic inflexibility and accumulating irrationalities in economic policy. There were few if any comparable complaints on the continent in the early postwar period -

10 In "The Political Economy of Comparative Growth Rates", in US Economic Growth, vol. 2, Joint Economic Committee, Congress of the United States, Hearings of the Joint Economic Committee for November 10, 1976, pp. 105-112; and "Comment", in The Market and the State: Essays in Honour of Adam Smith, eds. Thomas Wilson and Andrew Skinner (Oxford Univ. Press, 1976), 105-112. There was an international conference in December, 1978, at the University of Maryland to assess and criticize an early draft of Rise and Decline. Though that 1978 draft and some of the papers of commentary presented at that conference were circulated widely, the proceedings of this conference were published only later in Dennis Mueller, ed., The Political Economy of Growth (Yale U. Press, 1983). My use of the term "institutional sclerosis" in the 1978 paper is on pages 35 \& 46-49 of that book, and other participants in the conference, such as $\mathrm{K}$. Choi (pp. 57-78), J.-C. Asselain and C. Morrisson (p. 158) and D. Mueller (p. 268) also used the term to label my argument.

11 Herbert Giersch, "Gegen Euro-Sklerose", Die Wirtschaftswoche, 33 (August 12, 1983), and "Eurosclerosis", Institut fur Weltwirtschaft Discussion Paper \# 112 (1985). See also the Financial Times (Sept. 11, 1984) and Time (January 30, 1984). Lindbeck's essay is "The Emerging Sclerosis in the Western Economies" (Institute for International Economics, University of Stockholm, 1982).

12 Ingemar Stahl and Kurt Wickman, Riv bostadspolitiken (Stockholm: SNS, 1992). 
there is apparently a widely observed accumulation of distortions with social aging.

\section{Distinctive Institutions and Common Processes}

Those who are skeptical about whether there are any general principles governing economic growth in countries with very different institutions and histories will want to question whether the general model in Rise and Decline and its collateral works can be reconciled with the great institutional and historical differences across countries. Thus I face the challenge of showing how the general theory could be true, given the significance that idiosyncratic characteristics of each country can have for economic growth.

But this challenge is also an opportunity. The institutional and historical differences across countries can also be used to test, in a different way, whether the argument in Rise and Decline fits the facts of experience. If we agree about the important special institutional and historical features of a country, and if it is also clear how the general theory, if true, should be manifest in a country with those special institutional or historical characteristics, then we can test to see if exactly this manifestation is in fact observed. If the general principle shows up in a theoretically predicted way in each diverse institutional and historical setting, then that provides additional evidence that the principle is true. Just as we know that a fluid is water when we know the temperatures at which it freezes and turns to steam, so we can have more confidence in a theory if the sclerotic processes vary across countries in a way that is consistent with that theory.

In testing the argument in this way, it will be convenient to distinguish different classes of cases. Some of these classes have been analyzed elsewhere and will only be mentioned here. Another class of cases is sufficiently straightforward that it can be evoked in a couple of paragraphs. A final class, the NordicTeutonic class, is more complex and will require a more elaborate analysis. Most of the rest of this paper will be devoted to dealing with this last type of sclerosis, but I shall touch first on those cases that can here be dealt with more briefly. 


\section{Anglo-American}

The sclerotic process that manifested itself in the developed English-speaking countries has already been analyzed in Rise and Decline, so it is now only necessary to give it a separate name. It can conveniently be called the "Anglo-American" or (since it covers the developed democracies that were once part of the British Empire) the "English-speaking" form. The way in which hyper-pluralistic organizational structures and collusional patterns evolve in the Anglo-American type of context has also been described elsewhere, and thus can readily be compared with the other patterns of evolution that will be referred to or described in the rest of this essay.

\section{Mercantilistic}

Most of the countries of the Third World constitute another class of cases. The less developed countries have poor transportation and communication systems that, in combination with the difficulties of collective action, normally make organization of rural interests impossible. Their governments tend to be influenced disproportionately by organized small-group interests in the major urban areas and especially in the capital city. These organized interests gain from protection and subsidies to activities in which most of the Third World countries do not have a comparative advantage. Because of this, they suffer from what I call a "perverse policy syndrome". Since I have dealt with this class of cases in Rise and Decline and in some articles 13 . I will say no more about it here. Since Adam Smith first dealt with this class of cases (in analysis of pre-industrial Europe in the Wealth of Nations) and diagnosed it in a similar way, let us use his term, "mercantilism" to label this form of sclerosis.

\section{Red Devolution}

This form of institutional sclerosis has also been dealt with elsewhere ${ }^{14}$. The types of special-interest collusion that the theory predicts will emerge in societies without freedom of organization and with a Soviet-style economic organization are, of course, dramatically different from those that are pre-

13 "The Exploitation and Subsidization of Agriculture in Developing and Developed Countries", op. cit. and "Space, Agriculture, and Organization", American Journal of Agricultural Economics, Vol. 67, No. 5, December 1985, pp. 928-937

14 Peter Murrell and Mancur Olson, "The Devolution of Centrally-Planned Economies", Journal of Comparative Economics, 15 (1991), pp. 239-65. 
dicted to emerge in developed democracies with market economies. Most of the specific features that the theory predicts will characterize the evolution of Soviet-type societies also differ from those that characterize the sclerotic process in democracies with market economies. Because the Soviet-type societies lack various countervailing and corrective forces that characterize the market democracies, they develop a more severe sclerosis than western societies do.

\section{Healing-of-Divisions Sclerosis: southern Europe}

Societies differ in the degree to which they are divided over fundamental beliefs. Though there are divisions about government policy in all societies, in some there are also intense disagreements about what fundamental principles should govern the organization of society. The dangers and disadvantages for $a$ society of intense divisions about fundamental issues are well known. Societies that are deeply divided are less stable and this instability not only directly endangers these societies, but also generates uncertainties that reduce business confidence and especially limit the inflow of foreign investment.

What is not so widely understood is that social divisions can also favor economic growth by inhibiting some collective action that reduces social efficiency and dynamism. If collective action is to occur, there must be some limit to the intensity of divisions among those who would engage in collective action. Collective action by definition requires cooperation and concerted effort. Normally cartelization and collusion to fix prices and wages can occur only if everyone in some industry, craft, or occupation is willing to go along? with it. A cartel cannot monopolize the supply of any type of good or labor if any suppliers who can supply a large part of total demand refuse to cooperate. This is one of the reasons why organizations for collective action prefer to have a socially homogeneous membership.

By and large, the most seriously divided societies in Europe in the early postwar years were the societies that had simultaneously large numbers of Roman Catholics and large Communist Parties: the Mediterranean societies, especially Italy and France. No doubt these societies suffered some loss of foreign investment and some capital flight and other problems because of the uncertainty and tension arising from their social divisions.

In general, the social divisions in these societies did not prevent collusion or cartelization among large private firms, since almost all of those who owned or managed substantial private firms were anti-communist. Since the Com- 
munists were never in the central government, the state-owned firms also were not under communist management (though in Italy apparently there were systematic disagreements at a more encompassing level about some matters between the often left-Catholic managed government-owned firms in INTERSIND and the privately owned firms in CONFINDUSTRIA) ${ }^{15}$. So generally, the southern European societies had many powerful trade associations, cartels, and oligopolistic collusions, especially in the years before the Common Market.

The social divisions did, however, work against effective cartelization of the labor force in the early postwar years. There were separate communist, Catholic, and socialist unions, and these unions were often in conflict not only in the society at large, but also in particular industries, crafts, and enterprises. These divisions made it much more difficult for unions to obtain the powerful selective incentives needed to build up stable dues-paying memberships and large strike funds - that is, they worked against closed shops and other forms of compulsory membership. Union dues and union density tended to be lower in southern Europe than in Britain, Scandinavia, or Germany. (Interestingly, as the present argument would predict, the religious-ethnic division in Northern Ireland is said to have made labor unions at times less strong there than in other parts of the United Kingdom.) The competing unions in each workplace also sometimes negated each other. The social divisions, and each group's fear of being permanently repressed, worked against the solidarity needed for strikes that could outlast employers.

The labor unions in the southern European countries were able to stage conspicuous demonstrations, and they could often organize brief strikes, even in the early postwar period. They made the left-wing forces in politics more important than they would otherwise have been.

For the most part, however, the societies that were most sharply divided between Catholics and Communists did not have what in the United States has been called "business unionism". That is, they did not have unions whose members shared a consensus about the acceptability of the existing social order and thus were able to focus single-mindedly on obtaining the strike funds and control over the workforce needed for effective cartelization of the supply of labor in some firm, craft, or industry. At the same time, the unacceptability to the majorities of a Communist Party in the governing coalitions (until President Mitterrand in France organized a coalition with the Communists that left

15 I am thankful to G. Toniolo for helpful criticism on this point. 
them impotent) meant that the Communists did not have as large an effect on economic policy as might be expected from their numbers.

Thus there are some respects and circumstances in which, paradoxically, "communism is good for capitalism". This paradox should not be overdrawn. The southern European societies were endangered and, in some important respects, damaged by their deep divisions over Communism, Catholicism, and what constitutional order should be chosen. Their ideological-religious division could not have had any large impact on the cartelization of firms, and these societies appear to have lost a good deal from that type of cartelization. Still, there can be no doubt that there is an important and neglected element of truth in the paradox.

The foregoing argument about social divisions applies mainly to the early postwar period in France and Italy. The divisions over the constitution of society in southern Europe had diminished greatly even before the collapse of communism. With the collapse of the Soviet-type societies, both communism and fear of communism have nearly disappeared.

The logic of the theory leads one to expect certain special features in the sclerotic process in postwar southern Europe. Cartelization of labor markets would be expected to proceed more slowly than it would otherwise have done. The political focus of labor unions would be relatively larger and the cartelistic element somewhat smaller than in societies of lesser social divisions.

The healing of divisions would make the devolution of these societies resemble the English-language and north European societies more as time goes on. As social divisions heal, these societies would reap a direct gain from improved confidence in the investment climate.

They would also lose from an increasing institutional sclerosis.

In short, the aging process in southern Europe would, by the logic of the argument, tend to be accompanied by a healing of social divisions that would bring diverse social benefits at the same time that it brings new types of damage from cartelistic collective action. 


\section{Devolution of Encompassing Interest Groups: northern Europe}

As we recall, the basic logic in Rise and Decline implies that, if an organized interest is sufficiently encompassing, it will not have an incentive to engage in anti-social behavior that a narrow special-interest group has. A disciplined labor union or employers' association that represents, say, 50\% of the income-earning capacity of a country, will bear on average half of any losses it imposes on society. Thus it will cease any redistribution to itself when the marginal social losses that result from this redistribution are twice as large as its gain at the margin from the redistribution. It will have no incentive to engage in the extremely anti-social redistributions that are advantageous for a group that represents only a narrow interest such as an industry or occupation. Indeed, it has been proven elsewhere 16 that if an interest is sufficiently encompassing - if it is a "super-encompassing" interest - then self-interest, paradoxically, keeps it from taking any redistribution whatever from the rest of society, and motivates it to provide socially optimal supplies of public goods.

In a few (mostly small and homogeneous) societies, encompassing interest organizations were created by quasi-constitutional settlements utilizing, among other things, the power of government (or of occupation authorities). In Sweden, the encompassing arrangements were worked out before World War II and (since Sweden was not occupied or even a combatant in the war) continued unbroken through the war. In the case of Norway, Austria, and Germany, these arrangements date from after the war. At the beginning, in the cases of Norway and Sweden, and certainly of Austria, it was at most a moderate exaggeration to say that there was only one big union that represented all manual workers and only one big employers' organization representing all substantial firms. This was never true in Germany, but that country's structure of labor unions and business organizations was nonetheless relatively encompassing, especially by the standards of the English-speaking countries.

As the foregoing logic would suggest, the countries with encompassing interest organizations worked very well in the 1950's and 1960's. But as time has gone on, their economic performance has deteriorated considerably and, in the case of Sweden, dramatically.

This raises the question: How do societies with encompassing interest organizations change over time? When I was writing Rise and Decline, I had no

16 In Martin C. McGuire and Mancur Olson, Jr., "The Economics of Autocracy and Majority Rule: The Hidden Hand and the Use of Force", (IRIS, Univ. of Maryland and Univ. of California, Irvine, 1994 and forthcoming in The Journal of Economic Literature). 
idea what governed the evolution of such organizations, so that book is cautious and agnostic about how such organizations would work out in the long run. But, as I realized when writing some later articles on this subject ${ }^{17}$, the logic of the matter is so clear that I ought to have seen it from the start.

Though encompassing political parties and offices in certain types of electoral systems can remain encompassing for indefinitely long periods, encompassing interest organizations, such as business organizations and labor unions, are eventually bound to devolve implicitly or explicitly into narrow specialinterest groups.

The underlying logic can best be understood by comparing the incentives that face political parties in countries with electoral rules that generate two-party systems with the incentives facing organized groups in some other situations. In elections such as those for the House of Commons in the United Kingdom or in presidential elections in France or the United States, the candidate with a plurality - the "first past the post" - wins. There is no reward for the party that represents a block of voters but never comes in first. Therefore, though small parties can thrive under proportional representation, there is no incentive under winner-take-all electoral rules to set up political parties to serve the interests of the firms in any one industry, or the workers in any one occupation, or any other group too small to have a chance of coming in first. As has long been known from Duverger's Law, in such electoral systems there is a tendency toward a two-party system. Thus encompassing political parties in countries with plurality-winner electoral systems can last indefinitely.

The situation over the long-run is dramatically different for encompassing interest organizations such as employers' associations or labor unions. Lobbying and cartelistic organizations do not need a majority or even a plurality of the society to profit from collective action. All a collusion or cartel needs is control over the supply in a single market. All a lobby needs is enough resources to hire a lobbyist, or to make campaign contributions, or to provide enough campaign workers to make a difference in crucial districts, and so on. A trade association of firms in a particular industry or the union that represents the workers in a single craft or industry will normally be large enough to have significant lobbying power, even if the members of the organization in the aggregate obtain only a minute share of the national income. They are

17 "A Theory of the Incentives Facing Political Organizations: Neo-Corporatism and the Hegemonic State", International Political Science Review, Vol. 7, No. 2, April 1986, pp. 165-189 and "An Appreciation of the Tests and Criticisms", Scandinavian Political Studies, Vol. 9, No. 1, 1986, pp. 65-80. 
therefore in a very different situation from a political party in a country with electoral rules that favor a two-party system.

To understand the decisive significance of this for the evolution of encompassing organizations, we begin by assuming an ideally encompassing system with one encompassing labor union representing all workers and one encompassing organization representing all of business.

A union representing all workers in the country, if it acts in the best interests of its clientele, strives in the labor market to obtain the highest possible real wages for workers as a whole. The highest possible incomes for workers in this society will be attainable only if the economy is efficient, which it will not be if workers in particular occupations have monopolistic wage levels. Thus an encompassing labor union representing all workers would work for uniform wage levels for each skill level throughout the economy.

An encompassing union will often maximize the real incomes of its constituency by using its political power to obtain some income redistribution through government to the income categories in which its membership mainly falls. But it cannot serve its membership by seeking special protection or subsidies for workers in particular industries or occupations: industry-specific and occupation-specific favoritism will reduce the efficiency and dynamism of an economy.

In the same way, an encompassing business organization will best serve its clients by opposing any industry-specific or firm-specific protection or subsidies, unless they repair specific market failures, and it will also resist any efforts to block entry into any industries, including especially those that have come to have unexpectedly high profits.

Consider now an individual industry or occupation in the domain of an encompassing business organization or labor union. Even if the encompassing entity represents business as a whole or labor as whole perfectly, an individual industry or occupation will obtain additional gains if it wins special-interest legislation or a monopoly price or wage for itself. Though special-interest legislation and cartelistic prices or wages for an industry or occupation are contrary to the interests of the encompassing constituency as a whole, they are still advantageous for a narrow interest within it. Remember that, so long as an industry or occupation earns only a tiny percentage of aggregate income, it will bear only a tiny share of the social losses from the distortions brought about by a redistribution to itself but will receive all of the redistribution. 
Thus, no matter how well an encompassing organization serves the encompassing constituency in which a given industry or occupation falls, industryspecific or occupation-specific lobbying or cartelization can obtain something extra.

Since the amount that an encompassing interest group will redistribute to its members is, as we found earlier, limited by its encompassing interest, whereas there is almost no limit to the amount of redistribution that is advantageous for a narrow interest, the activities of the narrow interest will normally be worth much more to its beneficiaries than the activities of an encompassing organization. Paradoxically, this is true even though many if not all of the narrow interests would have been better off if there had been no special-interest favoritism or cartelization by any group ! The reason is that, when the number of narrow interests is large, so the narrow groups do not interact strategically predation by one narrow group does not affect the likelihood of predation by another. Thus the unilateral action of each group takes no account of the losses to them all from their actions in the aggregate, so they continue witk anti-social action even if all of them would have been better off if there had not been any such action.

Unexpected developments that bring large gains or losses to the firms of workers in a given market can often open up exceptional opportunities for cartelization and lobbying 18 . As a society with encompassing organizations matures, more of its firms and workers will have found themselves in excepz

18 The workers in a line of work that is enjoying a boom will gain the most if they receive not only the wage premia that firms want to offer to attract additional labor, but also the far higher increases that come from blocking entry into the booming line of work or making the wage so high that there is little or no employer demand for additional workers. During the oil boom, the Norwegian helicopter pilots that served the oil rigs in the North Sea could make themselves far better off by demanding the exceptional raises their employers could afford than by sticking with the policy of the encompassing labor union. When an unexpectedly large devaluation of the Swedish Krona once made some manufactured exports exceptionally profitable, the Swedish engineering union decided to abandon centralized wage bargaining. Clearly, the encompassing interest of workers as a whole is normally best served by allowing those in other sectors to move into the booming lines, thereby expanding the work force that is too small and making wages higher than they would otherwise be in the areas that were not so lucky. Similarly, when adverse shocks reduce the demand for, say, shipbuilding labor, the workers in this industry have an incentive to demand subsidies for the industry in which they work. By contrast, workers as a whole lose when a society maintains uneconomic industries that cannot cover their costs without protection or other subsidies. Obviously, there are exactly parallel arguments showing similar conflicts of interest between the firms in a booming or declining industry and the owners of capital as a whole. 
tional circumstances where the rewards from abandoning or opposing the encompassing organizations are unusually great.

A political entrepreneur who promotes an organization that obtains a surplus by organizing collective action for a narrow group can consume part of it himself or herself.

Therefore, whenever the firms or workers in an industry or occupation have the small numbers or access to selective incentives that make collective action possible, there is always an incentive to organize for collective action, whether or not the industry or occupation is already represented by an encompassing organization.

Nevertheless, it takes a long time before a society comes to have a large number of narrow cartelistic and lobbying organizations. Whether an encompassing organization already exists or not, each industry, occupation, or other narrow group must overcome the difficulties of collective action in order to organize. This process slows down the devolution of societies with encompassing interest organizations.

On the other hand, the foregoing logic - and especially the logic that shows that it pays narrow interests to redistribute much more than any encompassing organization would - implies that the branch organizations of an encompassing business or labor organization have a powerful incentive to push for the interests of their own branch, even when this is very harmful to the interests of the membership of the encompassing organization as a whole. As subordinate units gain autonomy and as separate industry or occupational caucuses are formed, an encompassing organization will tend to become merely a clearinghouse for the separate interests of its subordinate parts.

It might seem that the problem of insubordinate branches and independent coalitions could be controlled by appropriate by-laws for the encompassing interest group or by government legislation that discourages independent action by branches or other non-encompassing organizations. Corporatist societies such as Fascist Italy and Franco's Spain did that with great severity. In political science and sociology, there are advocates of corporatism (or, as it is now sometimes called, neo-corporatism), and some of them propose government licensing or other devices to give a monopoly to corporatist pressure groups in democratic societies. 
The governments of some democracies have discouraged independent associations and favored established encompassing interest organizations in other ways as well, and this has delayed their devolution. But governmental edicts cannot permanently prevent the devolution of encompassing interest organizations, at least in democracies.

There is no way that corporatist legislation in a democracy can prevent a branch of an encompassing organization from pressuring the leadership of an encompassing organization on behalf of the branch's narrow interest. The branch can always press for the right to obtain a monopoly price or wage for itself or lobby within the encompassing organization to make it support special-interest legislation for the branch. This branch advocacy is bound to have some effect in the long run. The way to get elected to the leadership of an organization is to gain the favor of influential constituents. The leaders of branch units are accordingly important in determining who comes to lead an encompassing interest organization. The leaders of branch units often have an incentive to insist that only those candidates for central office that agree to allow them to set prices or wages separately in their own market, or who promise to support special-interest legislation for those in this market, will receive the branch's support.

Those subgroups of an encompassing organization that are not already separately organized in branches can organize a caucus or lobby within the encompassing organization to pressure it to serve the sectional interest at the expense of the encompassing interest, if they have small numbers or if selective incentives can be found. In the long run, how could a democratic society prevent subsets of members of an encompassing organization with a legal monopoly of representation from being controlled in large part by internal lobbies working on behalf of internal subgroups? Even if a democratic government stipulates that only specified organizations are allowed to petition the government, how in practice could it prohibit the creation of internal caucuses or organizations to lobby internally to change the policies of any legally established encompassing lobby?

The logic that has just been discussed seems to fit some developments in the Nordic and Teutonic economies. Some observers of Norway and Sweden have emphasized developments that are completely consistent with the logic that I have just set out. S. Lash has published an article entitled "The End of Neo-Corporatism? The Breakdown of Centralized Bargaining in Sweden"19. 
In this article he argues, from a Marxist and sociological perspective, "that there is a long-term trend toward decentralization of Swedish industrial relations". The Swedish economist Assar Lindbeck has argued (personal communication) that the actual policies of encompassing organizations in Sweden have apparently often been dictated by relatively small subsets of the membership with special interests; government bail outs of Swedish shipbuilding were not in the interest of Swedish labor as a whole, but the big union, the LO, presumably at the behest of its constituent units in the shipbuilding industry, favored such subsidies. Gudmund Hernes has described, in compelling detail, a large number of situations in both Norway and Sweden where once-encompassing interest organizations have been undone by breakaway organizations, by assertive sub-units, or by new organizations for collective action 20 .

No doubt there continue to be significant episodes of encompassing behavior in some interest groups in Austria, Norway, Sweden, Germany, and some other countries. This behavior has had no counterpart in narrow distributional coalitions. But, as I argued in articles published in 198621, we should expect to find fewer examples of encompassing interest group behavior as time goes on. Though some additional supporting evidence has emerged since then, it remains to be seen whether this prediction will be borne out in the long run.

We also need to test the foregoing argument about the devolution of encompassing organizations against evidence on economic performance. Economic growth has gradually been slowing down in all of the pertinent countries, and the deterioration in Swedish economic performance in the last few years has been especially striking.

Though this is consistent with the theory in Rise and Decline, that book argues that monocausal theories are wrong and that any complex reality is multicausal; there may well be other factors that account for the apparent consistency of the growth data with the theory. For example, the countries in which encompassing organizations have been devolving tend to have above average levels of egalitarian or welfare-state income redistribution. The exceptionally high levels of income redistribution in Sweden are especially well known, and in the 1950's West Germany redistributed as high a proportion of its income through welfare state programs as any country in the world. Probably the single best-known explanation of the general deterioration in economic performance in the Nordic and Teutonic economies is that it is due to the magni-

20 Acta Sociologica, vol. 34, no. 4 (1991), pp. 239-60.

21 "An Appreciation of the Tests and Criticisms" op. cit. and "The Incentives Facing Political Organizations..." op. cit. 
tude of their programs for egalitarian income redistribution and their correspondingly high tax rates. As we shall see, this extensive redistribution may not be independent of the present argument, but we must nonetheless be wary of the possibility that the economic slowdown is due not to the devolution of encompassing organizations, but to inefficiencies arising from the extensive egalitarian redistributions of income in these societies.

Similarly, the severe depression of the Swedish economy in the last couple of years is almost certainly partly due to various macroeconomic mistakes and disequilibria that are in some degree independent of the argument offered here. Therefore, because so many different causal factors are involved, we cannot know how well the available evidence fits the theory until much more detailed research has been done.

The high level of egalitarian income redistribution in the countries with devolving encompassing interest organizations raises at least three questions. First, why have these countries, and especially Sweden, chosen a more egalitarian redistribution of income than other countries? Second, in view of the huge divergence between marginal private and marginal social returns arising from the large welfare state subsidies and taxes, why have these countries done as well as they have? Third, why has the Swedish economy performed worse than the other countries in this category?

With respect to why there has been so much income redistribution, other factors may be more important, but I have hypothesized that the early postwar success with encompassing interest organizations led to overconfidence and to "overshooting" 22 , especially in the case of Sweden ${ }^{23}$. The successful economic performance at the same time that there was a substantial level of income redistribution persuaded many people that very much larger levels of income redistribution could be undertaken with little social cost. Since the deadweight losses from income redistribution almost certainly rise more than linearly with the magnitude of the redistribution and are multiplied by the distortions from special interests, the overshooting tended to have much higher costs than its advocates expected.

On the question of why the countries in this category have managed as well as they have, I have argued elsewhere that "explicit income redistribution" to

22 See Assar Lindbeck, "Overshooting, Reform, and Retreat of the Welfare State", De Economist, 1994, 142, pp. 1-19.

23 This is argued in my "Devolution of the Nordic and Teutonic Economies", American Economic Review, (May, 1995) 
low-income people brings about, for several neglected reasons, lower deadweight costs and much less retardation of innovation than the "implicit income redistribution" in the form of protection, regulation, and cartelization that is normally brought about by narrow special-interest groups 24 .

Therefore, in the early postwar period before their encompassing organizations had devolved much. Sweden and the other countries with encompassing organizations had relatively less deadweight loss from income redistribution in relation to other countries than might have been expected. This helps to explain why Sweden and the other Nordic and Teutonic countries worked as well as they did for so long.

On the third question of why Sweden is lately doing worse than the other countries with devolving encompassing organizations, we must remember that because of their participation or occupation in World War II, none of the other countries has any encompassing organizations with continuity from before World War II. But Sweden does - the "Swedish Model" or "Middle Way" has enjoyed continuity (and great international visibility) since the 1930's. Thus the country in which the devolution of encompassing interest organizations has apparently gone on the longest is not only a country that seems to have started overshooting with the welfare state relatively early, but also the country where this devolution has brought about the greatest deterioration in economic performance.

\section{Different Beginnings, Similar Endings}

When one puts the devolution of encompassing interest-group organizations in perspective, the parallel with the Anglo-American or English-speaking sclerotic processes becomes clear. Just as political entrepreneurs have an incentive to organize narrow organizations for collective action in a society without any such organizations, so they have an incentive to create such organizations - or to establish them by breaking off from larger organizations - in a system of encompassing organizations. In both situations, the political entrepreneurs must overcome the great difficulties of collective action, so they will not be able to create many organizations for collective action quickly. But some groups have the small numbers or access to selective incentives needed for organization and will eventually succeed in organizing in a stable society. When

24 This and other arguments that bear on the present problem are set out in my book on How Bright Are the Northern Lights? Some Questions about Sweden (Lund, Sweden: Institute of Economic Research, Lund University Press, 1990). 
the firms or workers in some industry or occupation are separately organized, either by the creation of a new organization or by breaking away from an encompassing organization, they have an incentive to use cartelistic and lobbying power to shift the distribution of income to their advantage, and to do this even if the deadweight costs to society are large in relation to the amount they gain. This is true no matter how well the unorganized society or the society-with-encompassing-organizations works. So the political entrepreneur's incentive to establish narrow coalitions for collective action is the same in both unorganized societies and in those starting with ideal encompassing organizations.

Though I did not realize this when I wrote Rise and Decline, encompassing organizations may delay - but they cannot by themselves prevent - the emergence of narrow special interests.

The result in the long run, if we abstract from any differences across societies in how well they understand the problem, is likely to be much the same whether societies set up encompassing organizations or not.

In 1970 Sweden was substantially ahead of Britain, for example, in per-capita income, even though it started modern economic growth much later and had acquired a similarly high level of organization for collective action Sweden's superior performance surely owed something to the fact that its organizations for collective action were encompassing rather than narrow. But there is no reason whatever to suppose that the societies that have had highly encompassing organizations will stay in front. On the contrary, unless they acquire a better appreciation of the problem than other countries, they seem destined to operate more like societies with narrow organizations for collective action as time goes on.

\section{Distinctive Institutions and Inescapable Logic}

If the foregoing analyses of "healing-of-divisions sclerosis" and of the "devolution of encompassing interest organizations" is read along with other publications on the sclerotic processes in Soviet-type societies, on Third World mercantilistic environments, and on the sclerotic process in the English-language countries, it becomes clear that, important as the differences in the structure of interest organizations across societies are, the similarities in 
the sclerotic process are nonetheless more fundamental. Encompassing organizations and social divisions are conspicuous, but the inconspicuous accumulation of industry-by-industry and occupation-by-occupation lobbying and collusion is likely to be more telling in the long run. The healing of social divisions and the devolution of encompassing organizations tends to make the continental European societies resemble the English-speaking countries more as time goes on.

Important as the institutional and historical differences across societies are, they cannot alter the laws of logic. The logical principle that organized interests have incentives to act in anti-social ways, when they have only a narrow or minuscule stake in society and the capacity to influence or control coercive power, but incentives to act in less harmful and sometimes even socially beneficent ways when they have a sufficiently encompassing stake, applies to all societies.

So does the logic of collective action: it is only small groups and those with access to selective incentives that can organize for collective action in any society. Thus groups like consumers, taxpayers, and the poor are not organized in any society, but in all societies more of the groups with the potential for collective action organize as time goes on.

The two logical principles on which the present theory is based are manifest in different forms in different types of societies, but they are always (along with other important factors in this complex and multicausal world) evident. The diverse manifestations of the theory in different types of societies indicate that the theory has not only parsimony and explanatory power, but also what the 19th century scientist William Whewall called "consilience": the capacity to explain quite diverse phenomena.

The foregoing analysis shows that, though a society cannot preserve an encompassing interest-group structure over the very long run, encompassing political parties can be viable indefinitely with the right electoral rules. Thus the logic of encompassing interests argues for electoral rules that discourage small political parties and, ideally, even promote two-party systems. In the United States, where the problem is the weakness of political parties rather than their number, institutional rules are needed that make the political parties stronger and more responsible.

The most important implication of the analysis, however, is that the only real solution is for societies to acquire a better understanding of economics 
and of the present argument. The problem, even in the societies that once had only encompassing interest organizations, is small organized minorities. Each of these tiny minorities will easily be defeated if the public wises up.

No historical process that is understood is inevitable. 


\section{Biographical Note}

MANCUR OLSON JR., Professor of Economics at the University of Maryland is the author of the Logic of Collective Action (1965) and The Rise and Decline of Collective Action (1982). 


\title{
Jean Monnet Chair Papers
}

\author{
European University Institute, Florence
}

CHRISTOPH BERTRAM/Sir

JULIAN BULLARD/

LORD COCKFIELD/ Sir DAVID

HANNAY/MICHAEL PALMER

Power and Plenty? From the

Internal Market to Political and

Security Cooperation in Europe,

April 1991, pp. 73

ROBERT GILPIN

The Transformation of the

International Political Economy, April 1991, pp.27

EDMOND MALINVAUD

Macroeconomic Research and

European Policy Formation

April 1991, pp. 58

SERGIO ROMANO

Soviet Policy and Europe Since

Gorbachev,

April 1991, pp. 25

BERNT VON STADEN

The Politics of European

Integration,

April 1991, pp. 33

HELGA HAFTENDORN

European Security Cooperation

and the Atlantic Alliance,

July 1991, pp. 42

THOMAS ANDERSSON/STAFFAN

BURENSTAM LINDER

Europe and the East Asian

Agenda,

October 1991, pp. 87
ROGER G. NOLL

The Economics and Politics of

Deregulation,

October 1991, pp. 89

ROBERT TRIFFIN

IMS International Monetary

System - or Scandal?,

March 1992, pp. 49

EGON BAHR

From Western Europe to Europe, June 1992, pp. 42

HELGE HVEEM

The European Economic Area and the Nordic Countries - End

Station or Transition to EC

Membership?,

June 1992, pp. 21

ERIC STEIN

Post-communist Constitutionmaking: Confessions of a Comparatist (Part I), August 1992, pp. 63

CAROLE FINK

1922/23 From Illusion to

Disillusion,

October 1992, pp. 19

LOUIS H. ORZACK

International Authority and

Professions. The State Beyond

The Nation-State,

November 1992, pp. 47 
VLADIMIR M. KOLLONTAI

Economic Reform in Russia

November 1992, pp. 43

RYUTARO KOMIYA

Japan's Comparative Advantage in the Machinery Industry:

Industrial Organization and

Technological Progress,

October 1993, pp. 60

GIULIANO AMATO

Problems of Governance - Italy

and Europe: A Personal

Perspective,

October 1994, pp. 39

JEREMY RICHARDSON

The Market for Political

Activism: Interest Groups as a

Challenge to Political Parties,

November 1994, pp. 37

RICHARD B. STEWART

Markets versus Environment?,

January 1995, pp. 53

JOHN GERARD RUGGIE

At Home Abroad, Abroad at

Home: International Liberaliza-

tion and Domestic Stability in the

New World Economy,

February 1995, pp. 64

DAVID VOGEL

The Relationship Between Environmental and Consumer Regulation and International Trade, February 1995, pp. 44

JOHN WILLIAMSON

Proto-EMU as an Alternative to Maastricht

March 1995, pp. 20
THOMAS C. HELlER

Joint Implementation and the

Path to a Climate Change

Regime

March 1995, pp. 49

NORMAN SCHOFIELD

Modelling Political Order in

Representative Democracies

June 1995, pp. 38

VOJIN DIMITRIJEVIC

The Fate of Non-Members of

Dominant Nations in Post-

Communist European Countries

June 1995, pp. 34

HORST SIEBERT

Eastern Germany in the Fifth

Year. Investment Hammering in the Basement?

September 1995, pp. 45

CAROL HARLOW

Codification of EC

Administrative Procedures?

Fitting the Foot to the Shoe or the

Shoe to the Foot

September 1995, pp. 34

FRITZ W. SCHARPF

Negative and Positive Integration in the Political Economy of

European Welfare States

November 1995, pp. 44

VINCENT WRIGHT

Industrial and Banking

Privatization in Western Europe:

Some Public Policy Paradoxes

November 1995, pp. 40 


\section{ROBERT O. KEOHANE}

Local Commons and Global

Environmental Interdependence:

Tragedy of the Commons or

Opportunity for Institutions?

November 1995, pp. 21

\section{SABINO CASSESE}

The Difficult Profession of

Minister of Public

Administration

December 1995, pp. 31

MANCUR OLSON JR.

The Varieties of Eurosclerosis:

The Rise and Decline of Nations since 1982

December 1995, pp. 37 
